\title{
Study on Haloalkaliphilic Sulfur-Oxidizing Bacterium for Thiosulfate Removal in Treatment of Sulfidic Spent Caustic
}

\author{
Somaye Makzum ${ }^{1, a}$, Mohammad Ali Amoozegar ${ }^{* 1, b}$, \\ Seyed Mohammad Mehdi Dastgheib ${ }^{2, \mathrm{c}}$, Hamid Babavalian ${ }^{3, \mathrm{~d}}$, \\ Hamid Tebyanian $^{4, e}$, Fatemeh Shakeri ${ }^{4, f}$ \\ ${ }^{1}$ Extremophiles Lab, Dept. of Microbiology, Faculty of Biology, College of Science, \\ University of Tehran, Tehran, Iran. \\ ${ }^{2}$ Research Institute of Petroleum Industry, Tehran, Iran. \\ ${ }^{3}$ Applied virology Research Center, Baqiyatallah University of Medical Sciences, Tehran, Iran. \\ ${ }^{4}$ Applied Biotechnology Research Center, Baqiyatallah University of Medical Sciences, \\ Tehran, Iran. \\ asomayemakzum@gmail.com, ${ }^{b^{*}}$ amoozegar@ut.ac.ir, ' dastgheibsmm@ripi.ir, \\ d h.babavalian@yahoo.com, 'tebyan.hamid@yahoo.com, 'Shakeri1363@gamil.com \\ ${ }^{*}$ Corresponding author
}

Keywords: Biotreatment, Sulfide-oxidizing bacteria, Sulfidic spent caustic

\begin{abstract}
Due to the disadvantages of physiochemical methods for sulfidic spent caustic treatment, attentions are drawn to the environmental-friendly biotreatments including sulfur-oxidizing haloalkaliphiles. Thioalkalivibrio versutus DSM 13738 was grown at alkaline (pH10) autotrophic medium with sodium carbonate/bicarbonate as the sole source of carbon and amended with sodium thiosulfate as the electron and energy source. The effect of various parameters including temperature $\left(25-40{ }^{\circ} \mathrm{C}\right), \mathrm{pH}(8-11), \mathrm{NaCl}$ concentration $(0.5-5 \% \mathrm{w} / \mathrm{v})$ and sodium thiosulfate concentrations (100-750 mM) was evaluated on bacterial growth and thiosulfate removal. This strain could eliminate sodium thiosulfate at very high concentrations up to $750 \mathrm{mM}$. The results showed that the highest specific growth rate was $\mathrm{pH} 9.5$ and thiosulfate removal of Thioalkalivibrio versutus occurred at $\mathrm{pH} 10.5$. The optimum salt concentration for thiosulfate removal was $2.5 \%$ $\mathrm{w} / \mathrm{v}$ and $5 \% \mathrm{NaCl}$ and specific growth rate elevated $2.5 \% \mathrm{w} / \mathrm{v}$. It was also specified that this strain thrives occurred in $37{ }^{\circ} \mathrm{C}$ and at 35 and $37{ }^{\circ} \mathrm{C}$ higher removal of thiosulfate. Following chemical oxidation of sulfide to thiosulfate, application of Thioalkalivibrio versutus could be promising for spent caustic treatment. Since thiosulfate is utilized as an energy source, highest removal efficiency occurred at marginally different conditions compared to optimal growth.
\end{abstract}

\section{INTRODUCTION}

Releasing a large amount of toxic effluent produced in petroleum industry leads into environmental pollution of receiving bodies of water and soils and constitutes serious toxicity for living organisms and hence, reduces the capacity of contaminated habitat for supporting life [1-5]. Spent caustic is one of the most complicated and hazardous wastewaters produced in various gas and oil sweetening processes in refineries and petrochemical plants [3, 6-8]. Although characteristics of spent caustics may greatly vary from a refinery to another, these wastewaters are generally studied in three different categories namely sulfidic, phenolic and naphthenic [6, 9-12].

Diluted caustic solutions $(\mathrm{NaOH}, 5-10 \% \mathrm{w} / \mathrm{w})$ are usually used for scrubbing hydrocarbon streams to absorb sulfur compounds such as $\mathrm{H}_{2} \mathrm{~S}$ and thiols and finally this process results in sulfurcontaining waste water known as sulfidic spent caustic (SSC). This harmful waste has alkalinity over 12 , salinity of 5-12\% w/wand high sulfide (HS ${ }^{-}$and $\mathrm{S}^{2-}$ ) level exceeding $2-3 \% \mathrm{w} / \mathrm{w}[8,13-$ 15]. Sulfidic spent caustic may also contain toxic organo-sulfuric compounds such as methanethiol, and aromatic hydrocarbons like benzene $[15,16]$. 
Discharge of these wastes without proper treatment may impose catastrophic environmental issues. In industrial applications, extreme alkaline wastes have been generally neutralized with sulfuric acid and subsequently released to the environment. Nowadays physicochemical methods such as wet air oxidation (WAO), advanced oxidation and the MEROX process, as well as biological methods are proposed for the treatment of sulfidic spent caustic [17-20]. among which biological systems could be advantageous due to lower cost and higher safety [21]. The limited number of researches conducted on the biotreatment of sulfidic spent caustic mostly focused on the application of neutrophilic sulfur bacteria belonging to the genus Thiobacillus, where the stream needs to be diluted in order to decrease the $\mathrm{pH}$ and salinity levels [16, 22-24]. On the other hand, at $\mathrm{pH}$ levels below 9, most of the dissolved sulfide would be released as toxic hydrogen sulfide into the atmosphere $[25,26]$.

Recently, a specialized group of haloalkaliphile sulfide-oxidizing bacteria (HA-SOB) were obtained from soda lake sediments. These obligate autotrophic bacteria belong to gamma subdivision of the proteobacteria and are divided into Thioalkalimicrobium, Thioalkalivibrio and Thioalkalispira [27, 28]. To overcome acute sulfide toxicity towards bacteria, a two-step process was suggested by Marco de Graaff in 2012, in which sulfide was auto-oxidized to non-toxic thiosulfate in an aeration process and then remaining sulfide and thiosulfate was biologically oxidized to sulfate [14]. It has been shown that sulfide reduces the growth rates of alkaliphilic sulfur-oxidizing bacteria at concentrations of about $3 \mathrm{mM}$, while at higher concentration of $6 \mathrm{mM}$, is completely inhibitory [21]. Chen and Morris expressed that sulfide oxidation produces polysulfide, $\mathrm{S}_{4}{ }^{2-}, \mathrm{S}_{5}{ }^{2-}$, and thiosulfate [29]. The intermediates formed during chemical sulfide oxidation are less toxic to alkaliphilic sulfur-oxidizing bacteria and inhibits their activity at least six times less than sulfide. Gonzalez$\mathrm{S}^{\prime}$ anchez showed that during chemical oxidation, almost one-third of sulfide was converted to thiosulfate and sulfate [30]. Researchers also reported that sulfide oxidation increases at high $\mathrm{pH}$ values $[29,31]$.

Among haloalkaliphilic bacteria, the genus Thioalkalivibrio could thrive in extreme salt $(0.6-4 \mathrm{M}$ $\mathrm{Na}^{+}$) and alkaline ( $\mathrm{pH}$ 10.0-10.2) conditions [27, 28, 32]. All members of this genus could oxidize thiosulfate, sulfide and polysulfide in halo-alkaline conditions which makes them appropriate candidates for biotreatment of sulfidic spent caustic wastewater. In spite of the biotechnological importance of these extremophilic sulfur bacteria, little information is available regarding their thiosulfate utilization. In this study, optimal conditions of thiosulfate removal were investigated for the type strain of Thioalkalivibrio versutus DSM 13738 [27].

\section{MATERIAL AND METHODS}

\section{Microorganism and Medium Composition}

The bacterium, Thioalkalivibrio versutus DSM 13738, isolated from Hadyn Soda Lake in southeast Siberia by Sorokin, was used throughout this study [27, 33, 34]. The obtained standard strain was checked by $16 \mathrm{~S}$ rRNA gene sequencing analysis. The basal mineral medium recommended by DSMZ for the growth of Thioalkalivibrio versutus was used in this study. This medium consisted of (g/L): $\mathrm{Na}_{2} \mathrm{CO}_{3}, 20 ; \mathrm{NaHCO}_{3}, 10 ; \mathrm{NaCl}, 5 ; \mathrm{K}_{2} \mathrm{HPO}_{4}, 1 ; \mathrm{KNO}_{3}, 0.5 ; \mathrm{MgCl}_{2} .6 \mathrm{H}_{2} \mathrm{O}, 0.1$ and $2 \mathrm{ml} / \mathrm{L}$ trace element solution which contains $(\mathrm{mg} / \mathrm{L})$ : EDTA, 5; $\mathrm{FeSO}_{4} .7 \mathrm{H}_{2} \mathrm{O}, 2 ; \mathrm{ZnSO}_{4} .7 \mathrm{H}_{2} \mathrm{O}, 100$; $\mathrm{MnCl}_{2} \cdot 4 \mathrm{H}_{2} \mathrm{O}, 30 ; \mathrm{CoCl}_{2} \cdot 6 \mathrm{H}_{2} \mathrm{O}, 200 ; \mathrm{NiCl}_{2} \cdot 6 \mathrm{H}_{2} \mathrm{O}, 20 ; \mathrm{Na}_{2} \mathrm{MoO}_{4} \cdot 2 \mathrm{H}_{2} \mathrm{O}, 30 ; \mathrm{CuCl}_{2} .2 \mathrm{H}_{2} \mathrm{O}, 10 ; \mathrm{H}_{3} \mathrm{BO}_{3}$, 300. The mineral base medium was buffered at $\mathrm{pH} 10$ with sodium carbonate/bicarbonate. Due to less toxicity, sodium thiosulfate was amended instead of sulfide as electron donor and energy source. Thiosulfate stock solution was sterilized separately and added at final concentration of $40 \mathrm{mM}$. For purity checking of the cultures, solid medium was prepared by mixing equal volumes of autoclaved $4 \%(\mathrm{w} / \mathrm{v})$ agar solution with the double-strength mineral base at $55-60{ }^{\circ} \mathrm{C}$ to prevent agar caramelization at high $\mathrm{pH}$. Fresh cultures were prepared on liquid mineral medium with a twomonth interval between transfers. For long-term preservation, concentrated bacterial biomass harvested by centrifugation, were suspended in glycerol $(10 \% \mathrm{v} / \mathrm{v}$, final concentration) and kept at $70{ }^{\circ} \mathrm{C}$ until used in inoculum preparation [27]. 


\section{Cultivation Experiments}

In this study, parameters with the highest impact on the autotrophic bacterial growth and removal of thiosulfate were determined considering biotreatment of spent caustic waste and effect of important parameters for growth and thiosulfate removal was assessed. The experiments were performed by adjusting the temperature (ranging from 25 to $\left.40{ }^{\circ} \mathrm{C}\right), \mathrm{pH}(8-11)$, sodium chloride $(0.5-5 \% \mathrm{w} / \mathrm{v})$, and sodium thiosulfate $(100-750 \mathrm{mM})$. For the preparation of the mentioned $\mathrm{pH}$ range $(8,9,9.5,10$, $10.5,11$ ), a set of carbonate buffers containing $2 \mathrm{M} \mathrm{Na}^{+}$was used. The effect of key parameters for growth and removal of thiosulfate was surveyed. Growth experiments were performed in triplicate; the data represent the average value with standard deviation $[35,36]$.

For pre-culture preparation, Thioalkalivibrio versutus was inoculated in a $250 \mathrm{ml}$ Erlenmeyer flask containing $50 \mathrm{~mL}$ basal mineral medium. The flask was incubated at $35{ }^{\circ} \mathrm{C}$ for 3 days to reach the

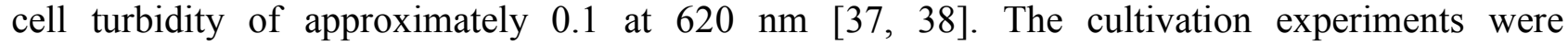
accomplished in $1000 \mathrm{ml}$ Erlenmeyer flasks using $200 \mathrm{ml}$ of culture medium with $5 \%(\mathrm{v} / \mathrm{v})$ of inoculum, prepared as described above. The flasks were incubated at $150 \mathrm{rpm}$ to fulfill the oxygen and mixing requirement. For monitoring biomass production and thiosulfate removal, $1 \mathrm{ml}$ samples were obtained from culture medium at three-hour intervals until the exhaustion of sodium thiosulfate. The rate of thiosulfate consumption by Thioalkalivibrio versutus was measured at different intervals to determine maximal thiosulfate removal rate [37, 39].

\section{Analytical Techniques \\ Growth assay}

Bacterial biomass was determined colorimetrically by measuring total protein content with Bradford method. Washed bacterial pellet of $1 \mathrm{ml}$ withdrawn sample was suspended in $0.1 \mathrm{~N} \mathrm{NaOH}$ and boiled for 1 hour to lyse bacterial cells. The cell debris along with elemental sulfur was removed by centrifugation at $11500 \mathrm{rpm}$ for 10 minutes and the supernatant was used for total protein measurement by Bradford method (Bradford 1976). Bovine serum albumin (BSA) solutions, diluted in the mentioned mineral base medium, were used as a standard.

\section{Chemical analysis}

Thiosulfate consumption in batch culture was measured by standard iodometric titration. This method is based on the titration of thiosulfate with iodine in the presence of starch as indicator. To prevent sulfate formation, the reaction should be performed at acidic $\mathrm{pH}$ after neutralization of medium with acetic acid $50 \%(\mathrm{v} / \mathrm{v})$. Since thiosulfate would decompose at acidic $\mathrm{pH}$, the titration should be done rapidly. For this purpose, $1 \mathrm{ml}$ sample was centrifuged at $11500 \mathrm{rpm}$ for $10 \mathrm{~min}$ to remove bacterial biomass and produced sulfur. Supernatant was titrated by iodine based on the formation of the blue starch complex as the endpoint $[37,40]$.

\section{RESULTS}

The harmful effect of hydrogen sulfide has triggered the application of a two-step treatment process for spent caustics in which the chemically formed thiosulfate is utilized by haloalkaliphilic sulfideoxidizing bacteria. Important parameters affecting thiosulfate removal rate in Thioalkalivibrio versutus were elucidated in this study.

\section{Effect of substrate concentration}

Thioalkalivibrio versutus could grow at extremely high concentrations of thiosulfate up to $750 \mathrm{mM}$ (that at this study was surveyed). Specific growth rate at a concentration of 100, 250, 500 and 750 was measured to be $0.069,0.06,0.05$ and $0.06 \mathrm{~h}^{-1}$. At a substrate concentration of $100 \mathrm{mM}$, complete removal of thiosulfate was achieved at $76^{\text {th }}$ hour, whereas at a concentration of 250,500 and $750 \mathrm{mM}, 46 \%, 43 \%$ and $10 \%$ of the substrate were respectively removed at $76^{\text {th }}$ hour. On the other hand, at low concentration of thiosulfate $(100 \mathrm{mM})$, produced elemental sulfur was further oxidized to sulfate to serve the energy requirements of bacterial cells after thiosulfate depletion, which resulted in the disappearance of sulfur particles from the media. As shown in Figure 1, increased substrate level neither imposed toxicity nor promoted the growth of the culture, but resulted in sulfur accumulation in the media. 

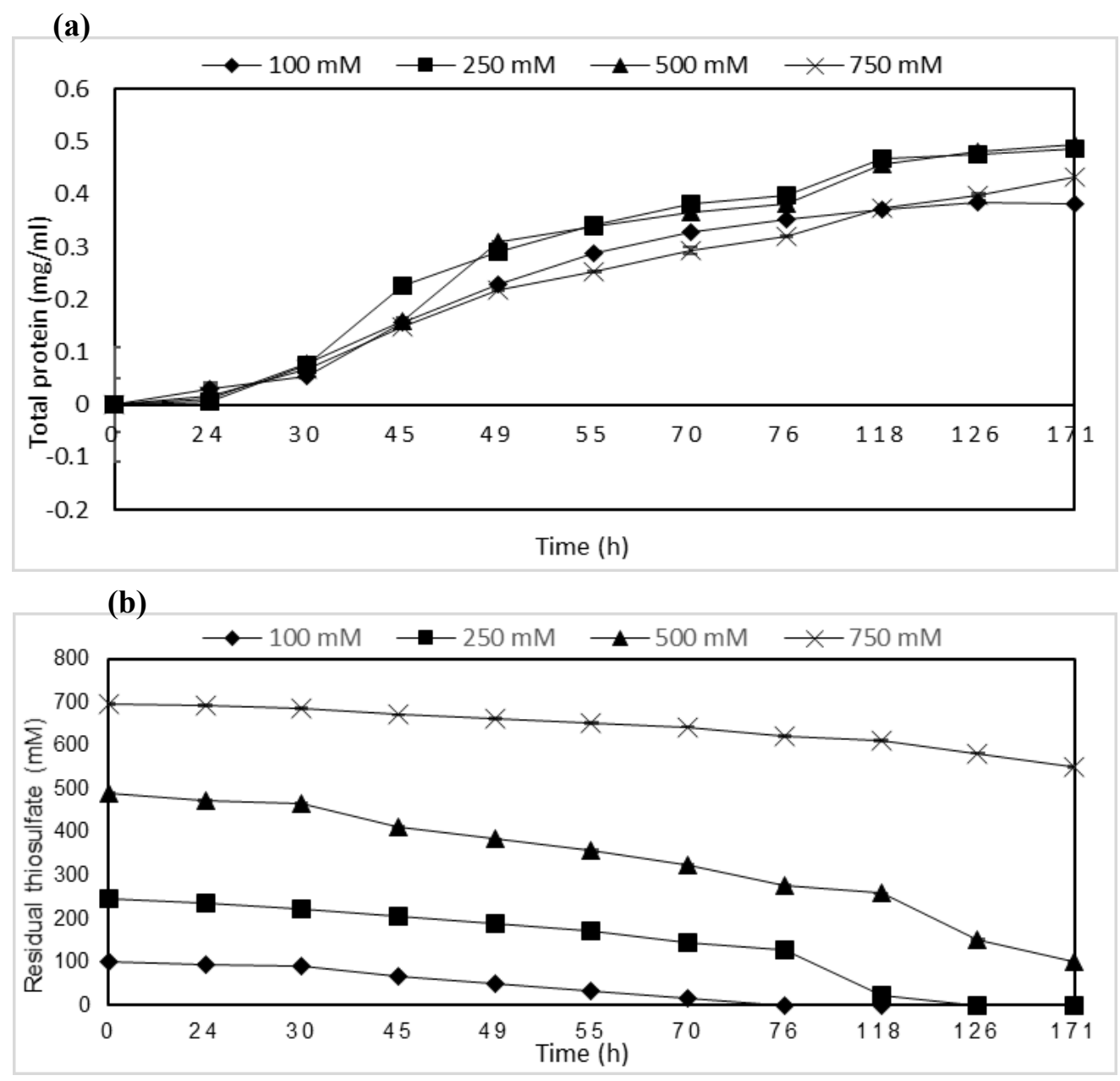

Figure 1: Comparison of (a) growth and (b) thiosulfate removal at different concentrations of sodium thiosulfate $(100,250.500$ and $750 \mathrm{mM})$.

\section{Effect of pH}

As depicted in Figure 2, no growth and thiosulfate removal were observed at extreme $\mathrm{pH} 11$ after 70-hour incubation. The highest specific growth rate was measured at $\mathrm{pH} 9.5,0.077 \mathrm{~h}^{-1}$, in which thiosulfate was completely utilized in $50^{\text {th }}$ hour. The specific growth rate at $\mathrm{pH} 8,9,10$ and 10.5 was measured to be $0.034,0.065,0.076$ and $0.064 \mathrm{~h}^{-1}$ respectively. The final biomass concentration at $\mathrm{pH} 9.5$ reached to $0.28 \mathrm{mg} / \mathrm{ml}$ and highest biomass concentration was calculated at same $\mathrm{pH}$. The rate of thiosulfate removal at $\mathrm{pH} \mathrm{9,9.5,10} \mathrm{and} 10.5$ was calculated to be $0.76 \mathrm{mMh}^{-1}$ while at $\mathrm{pH} 8$, the rate of thiosulfate removal was $0.56 \mathrm{mMh}^{-1}$. $\mathrm{pH}$ changes during the period of growth were followed and was shown no significant change at different times of incubation that can result from low acid production or stop the process until the step of the production of sulfur.

\section{Effect of temperature}

Bacterial growth and thiosulfate consumption at various temperatures are plotted in Figure 3. During 70-hour incubation period, no growth and thiosulfate removal were observed at $40{ }^{\circ} \mathrm{C}$. At 35 ${ }^{\circ} \mathrm{C}$ and $37{ }^{\circ} \mathrm{C}$ the strain began to grow following a 20 -hour lag phase total protein concentration reached to 0.29 and $0.27 \mathrm{mg} / \mathrm{ml}$, respectively and sodium thiosulfate was completely consumed in both cultures at $41^{\text {th }}$ hour. The lag phase extended up to 25 hours at lower temperatures of 25 and 30 ${ }^{\circ} \mathrm{C}$. However, the final biomass concentration reached to $0.28 \mathrm{mg} / \mathrm{ml}$. Specific growth rates at 25 , 30,35 and $37{ }^{\circ} \mathrm{C}$ based on Monad equation were calculated as $0.08,0.082,0.087$ and $0.095 \mathrm{~h}^{-1}$. The highest rates of thiosulfate removal at 35 and $37{ }^{\circ} \mathrm{C}$ were calculated to be $1 \mathrm{mMh}^{-1}$. On the other hand, at 25 and $30^{\circ} \mathrm{C}$ thiosulfate was removed as $0.76 \mathrm{mMh}^{-1}$. 

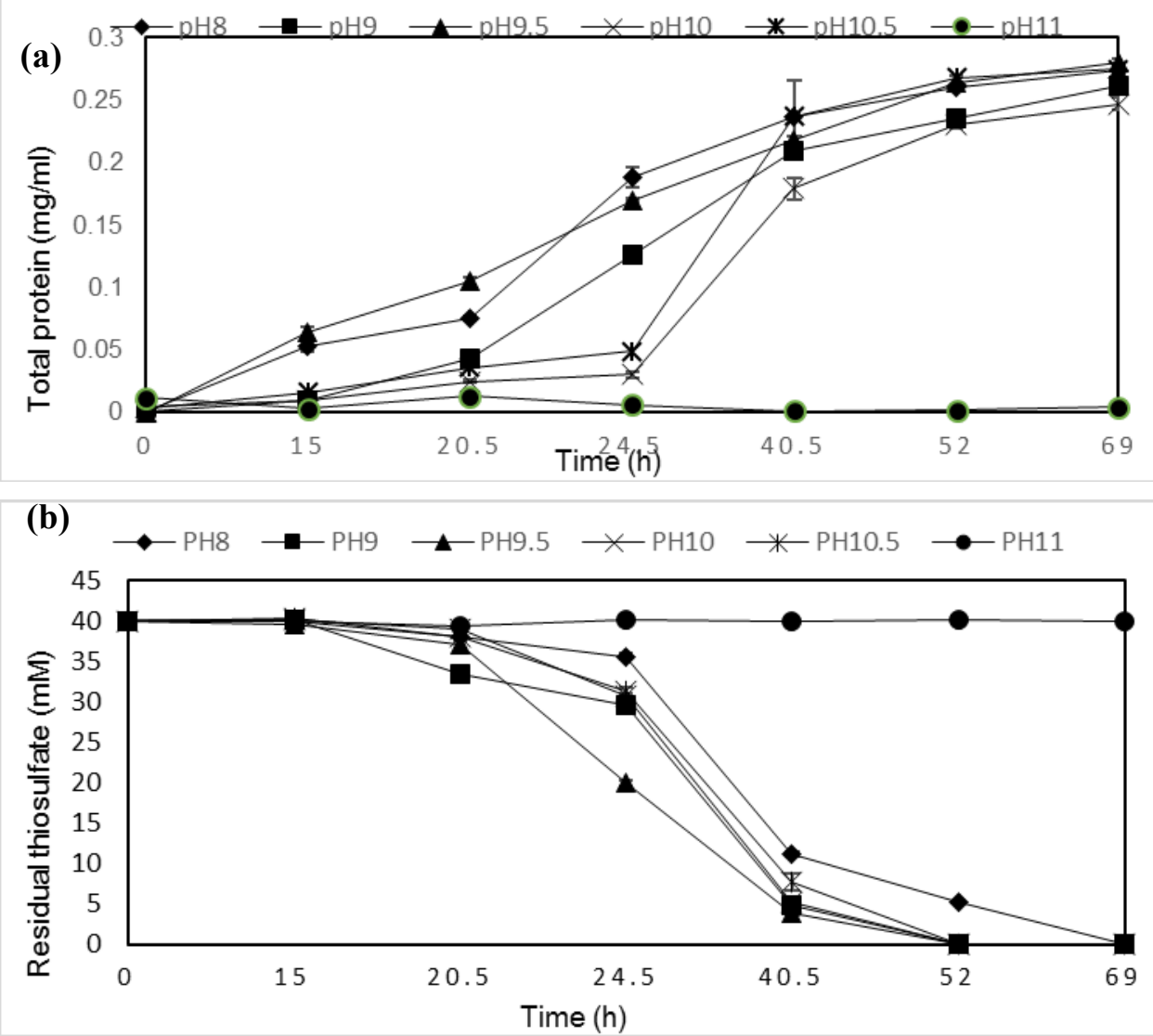

Figure 2: Comparison of (a) growth and (b) thiosulfate removal at different $\mathrm{pH}(8,9,9.5,10,10.5$ and 11).
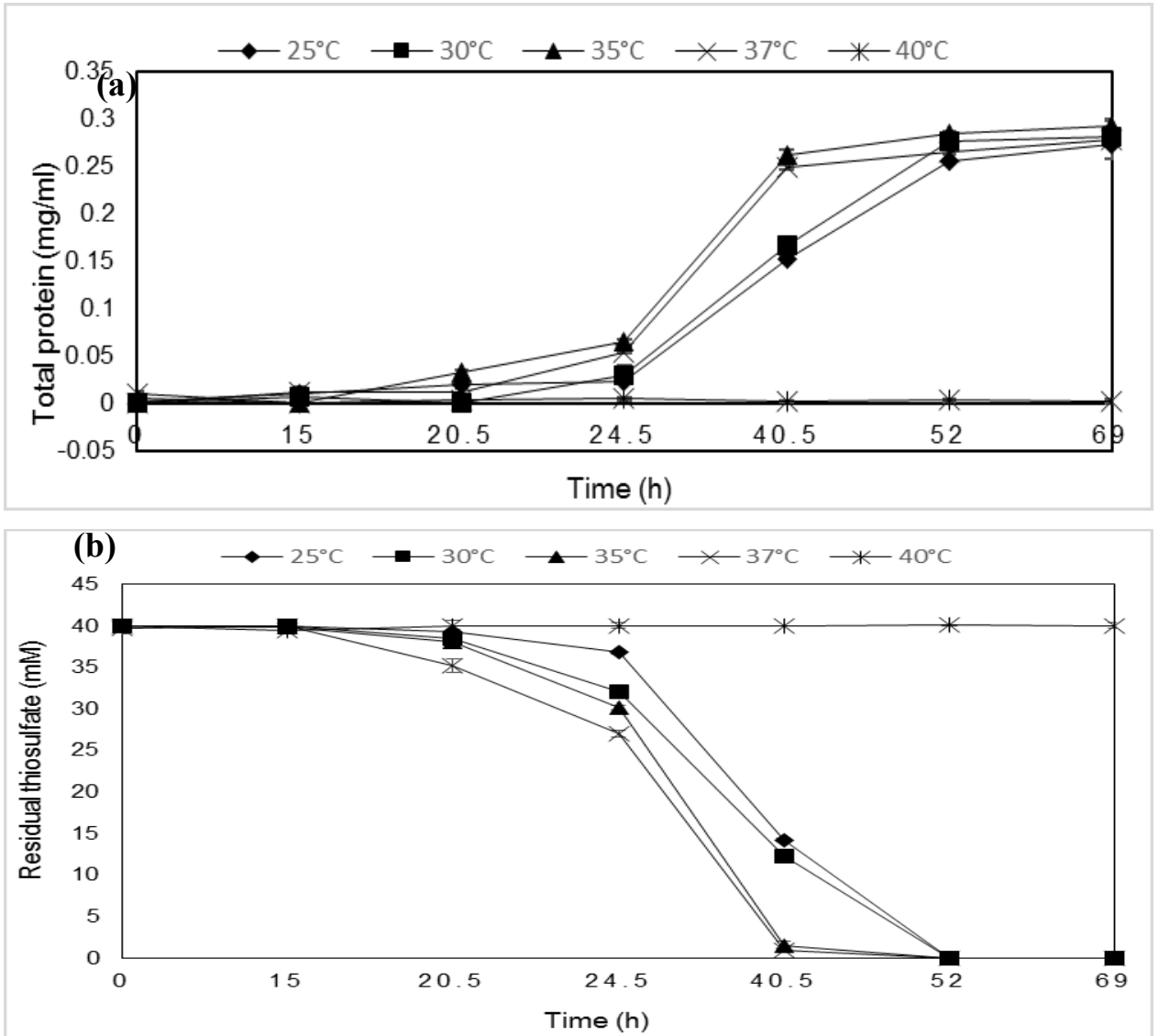

Figure 3: Comparison of (a) bacterial growth and (b) sodium thiosulfate removal at different temperatures $\left(25,30,35,37\right.$ and $\left.40{ }^{\circ} \mathrm{C}\right)$ 


\section{Effect of salt concentration}

Following a 24-hour lag phase, the highest growth rate was observed at $\mathrm{NaCl}$ concentrations of 2.5 $\% \mathrm{w} / \mathrm{v}$ with complete removal of sodium thiosulfate measured at $47^{\text {th }}$ hour-growth. Specific growth rate of $0.5,1,2.5$ and $5 \%$ of $\mathrm{NaCl}$ concentrations was calculated as $0.088,0.124,0.26$ and $0.193 \mathrm{~h}^{-1}$ respectively. The final biomass at $\mathrm{NaCl}$ concentration of $2.5 \% \mathrm{w} / \mathrm{v}$ reached to $0.31 \mathrm{mg} / \mathrm{ml}$. At NaCl concentration of $5 \% \mathrm{w} / \mathrm{v}$, sodium thiosulfate was completely removed after 47 -hour incubation and final biomass concentration was measured $0.29 \mathrm{mg} / \mathrm{ml}$. The rate of thiosulfate removal at $\mathrm{NaCl}$ concentration of 2.5 and $5 \% \mathrm{w} / \mathrm{v}$ was $0.85 \mathrm{mM} / \mathrm{h}$ while at lower $\mathrm{NaCl}$ concentrations of 0.5 and 1 $\% \mathrm{w} / \mathrm{v}$, the complete removal of thiosulfate was achieved after 69 and 52 hours and the rate of thiosulfate removal was measured as 0.57 and $76 \mathrm{mM} / \mathrm{h}$, respectively (Figure 4). The strain showed high salt tolerance with the lowest lag phase at 2.5 and $5 \% \mathrm{NaCl}$ concentration. However, the highest specific growth rate was showed at $2.5 \% \mathrm{NaCl}$.
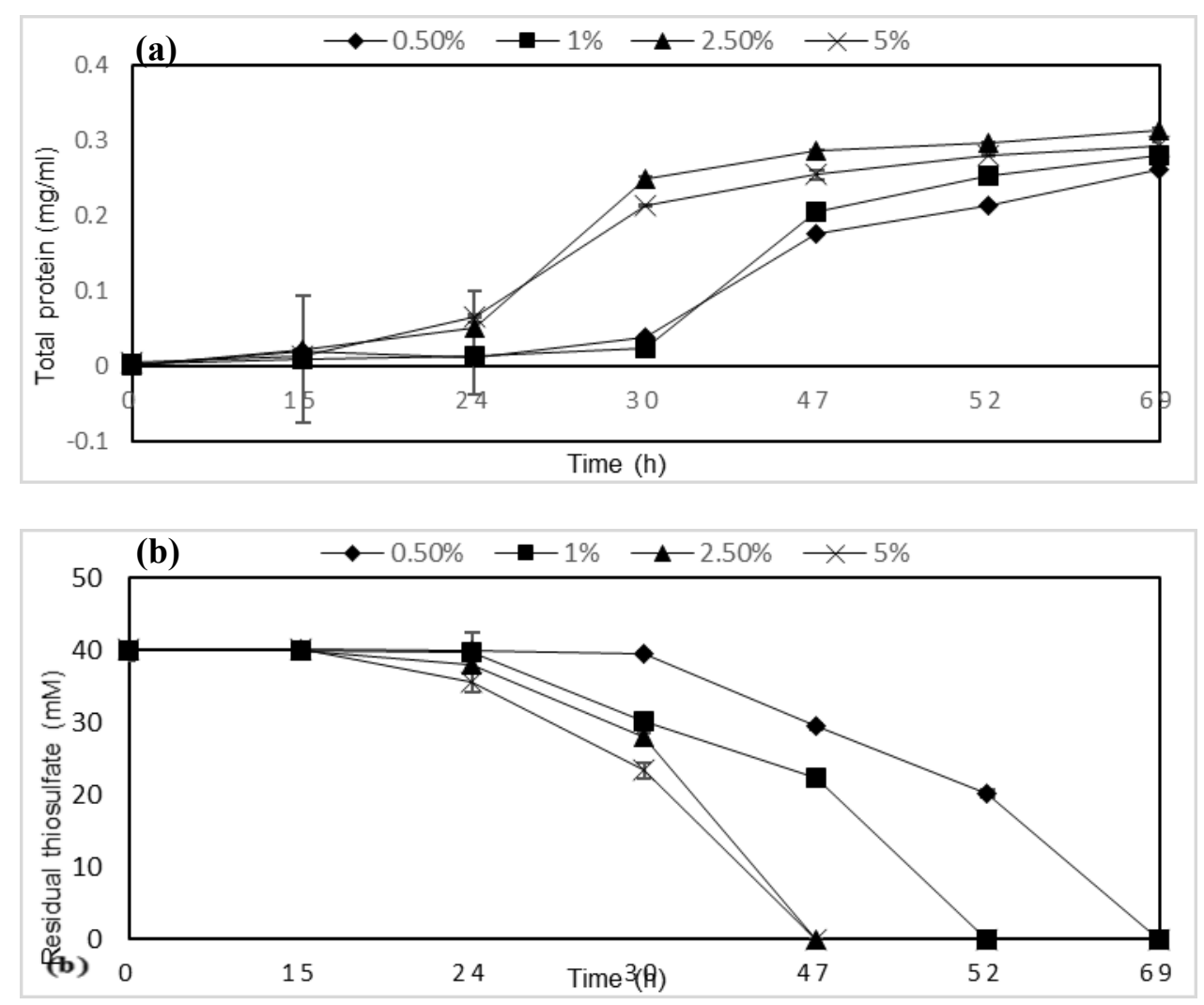

Figure 4: Comparison of (a) growth and (b) thiosulfate removal at different concentration of sodium chloride $(0.5,1,2.5$ and $5 \%)$.

\section{DISCUSSION}

Sulfidic spent caustic is a harmful waste for which biological method could be advantageous due to lower cost and higher safety. Subramanian in 1998 used aerobic enrichment culture containing mixed Thiobacilli to stimulate the treatment of the inorganic and organic sulfur of a spent caustic. This enrichment could treat an actual waste by low rate due to existing inhibitory components. Jin Myung Cha isolated a strain of Thiobacillus novelus from sewage capable of oxidizing S2O32- to S4O62- and S4O62- to SO42- [41]. In another investigation, where aerobic enrichment culture was immobilized in a novel support matrix, the efficiency depended on the maintenance of sulfide concentration below inhibitory levels [22].

Following the introduction of haloalkaliphilic sulfur-oxidizing bacteria by Sorokin in 2000 [28], the advantage of applying this microbial group for oxidation of sulfidic components in spent caustics was elucidated $[25,26]$. 
In 2007, an alkaliphilic sulfur-oxidizing consortium was exploited for the treatment of sulfidic spent caustic without significant dilution in which the efficiency of sulfide oxidation reached about $100 \%$ [21]. Marco de Graff and colleagues also showed that sulfide could be completely removed at $\mathrm{pH}$ $9.5, \mathrm{Na}+0.8 \mathrm{M}$ by applying a sulfur-oxidizing bacteria belonging to the genus Thioalkalivibrio [15].

In our study, optimal conditions for the growth and removal of thiosulfate was determined in batch cultures. The optimal temperature for growth was $37^{\circ} \mathrm{C}$ and maximum rate of thiosulfate removal was concluded at 35 and $37^{\circ} \mathrm{C}$ similarly, but no growth was observed at $40{ }^{\circ} \mathrm{C}$. Marco de Graff used Thioalkalivibrio at $35^{\circ} \mathrm{C}$, at alkaline condition by sulfide loading rates up to $27 \mathrm{mM}$ day-1and sulfide was completely oxidized to sulfate [15]. Accordingly, highest thiosulfate depletion, as the sole energy source could be achieved at a temperature slightly above the optimal growth conditions, in which extra energy is required for cellular activities and maintenance.

Haloalkaliphile bacteria tolerate alkaline $\mathrm{pH}$ by $\mathrm{K}+\mathrm{H}+$ pump, these bacteria make a gradient of $\mathrm{pH}$ that decreases cytoplasmic $\mathrm{pH}$ up to 2.3 unit. $\mathrm{CO} 32-/ \mathrm{HCO} 3-$ play an important role in producing alkaline $\mathrm{pH}$ in specific alkaline habitat. Similarly, the highest specific growth rate was observed at pH9.5 and the highest rate of thiosulfate removal was at $\mathrm{pH} \mathrm{9,9.5,10} \mathrm{and} 10.5$ with $0.76 \mathrm{mMh}^{-1}$. Sorokin at 2005 showed that optimal growth rate of Thioalkalivibrio versutus was at $\mathrm{pH} 9.5$. Because there were no significant differences in specific growth rate and rate of thiosulfate removal between $\mathrm{pH} 9$ to 10.5 and on the other hand higher $\mathrm{pH}$ have advantages due to reduced consumption of produced acid during oxidation of sodium thiosulfate. So it seems that $\mathrm{pH} 10.5$ is more suitable for the oxidation of the sulfur substrate. It is being shown that Haloalkaliphile chemolithoautotroph bacteria for optimal activity of RuBisCo enzyme need alkaline $\mathrm{pH}$. On the other hand, the optimal activity of enzymes existing at sulfur oxidation pathway in haloalkaliphilic sulfur oxidizing bacteria is in alkaline $\mathrm{pH}$ condition.

Results elucidated that higher specific growth rate was measured at $\mathrm{NaCl}$ concentration $2.5 \%$ (1.8 $\mathrm{M} \mathrm{Na}^{+}$). Whereas in a study conducted by Sorokin, the maximum growth rate was reported at less than $1 \mathrm{M} \mathrm{Na}^{+}$. The sodium salt is an osmotic compound that halophile microorganisms such as haloalkaliphiles need to resist to osmotic pressure. According to the results of Sorokin et al, Soda Lake makes approximately two timeless osmotic pressure than $\mathrm{NaCl}$ brines. In this study, by increasing concentration of $\mathrm{Na}^{+}$, specific growth rate increased up to $2.5 \%$ but at higher than the concentration of $\mathrm{NaCl}$-specific growth rate was diminished.

\section{CONCLUSION}

This bacterium was able to remove thiosulfate up to $750 \mathrm{mM}$. Although, at higher concentration of sodium thiosulfate, lower thiosulfate removal, could be explained by metabolic substrate saturation of the bacterial cells or presence of other limiting factors in the culture media. Haloalkaliphilic sulfur-oxidizing bacteria could tolerate harsh conditions of spent caustic and would be promising for biotreatment of this hazardous waste. Tolerance of Thioalkalivibrio versutus towards increased concentrations of thiosulfate is also an important criterion for biotechnological application, where the exploitation of a pretreatment stage for conversion of toxic sulfide to thiosulfate would pave the way for further oxidation. In addition, choosing proper conditions for thiosulfate oxidation activity could results in higher removal efficiency with minimal excess biomass production during wastewater treatment. 


\section{REFERENCES}

[1]. S. Najirad et al., Bioremediation of gasoil by two indigenous bacterial strains in contaminated soils, International Journal of Biosciences (IJB). 3(11) (2013) 71-76.

[2]. O.E. Idise et al., Modification of Bacillus cereus and Pseudomonas aeruginosa isolated from a petroleum refining effluent for increased petroleum product degradation, African Journal of Biotechnology. 9(22) (2010) 3303-3307.

[3]. P.L.F. van den Bosch, Biological sulfide oxidation by natron-alkaliphilic bacteria: application in gas desulfurization. 2008.

[4]. P.O. Okerentugba, O.U. Ezeronye, Petroleum degrading potentials of single and mixed microbial cultures isolated from rivers and refinery effluent in Nigeria, African Journal of Biotechnology. 2(9) (2004) 288-292.

[5]. J.W. Patterson, Industrial wastewater treatment technology, 1985.

[6]. G. Veerabhadraiah, N. Mallika, S. Jindal, Spent caustic management: Remediation review, Hydrocarbon Processing. 90(11) (2011) 41-46.

[7]. D.Y. Sorokin, A.J.H. Janssen, G. Muyzer, Biodegradation potential of halo (alkali) philic prokaryotes, Critical reviews in environmental science and technology. 42(8) (2012) 811-856.

[8]. J.F. Paulino, J.C. Afonso, New strategies for treatment and reuse of spent sulfidic caustic stream from petroleum industry, Química Nova. 35(7) (2012) 1447-1452.

[9]. M. Al Zarooni, W. Elshorbagy, Characterization and assessment of Al Ruwais refinery wastewater, Journal of hazardous materials. 136(3) (2006) 398-405.

[10]. R. Alnaizy, Economic analysis for wet oxidation processes for the treatment of mixed refinery spent caustic, Environmental Progress. 27(3) (2008) 295-301.

[11]. A. Olmos et al., Physicochemical characterization of spent caustic from the OXIMER process and sour waters from Mexican oil refineries, Energy \& fuels. 18(2) (2004) 302-304.

[12]. C. Maugans, M. Howdeshell, S. De Haan, Update: Spent caustic treatment, Hydrocarbon Processing. 89(4) (2010) 61.

[13]. J.A. Conner et al., Biotreatment of refinery spent-sulfidic caustic using an enrichment culture immobilized in a novel support matrix, Applied biochemistry and biotechnology. 84(1-9) (2000) 707-719.

[14]. M. de Graaff et al., Application of a 2-step process for the biological treatment of sulfidic spent caustics, Water research. 46(3) (2012) 723-730.

[15]. M. De Graaff et al., Biological treatment of refinery spent caustics under halo-alkaline conditions, Bioresource technology. 102(15) (2011) 7257-7264.

[16]. J. Sipma et al., Potentials of biological oxidation processes for the treatment of spent sulfidic caustics containing thiols, Water research. 38(20) (2004) 4331-4340.

[17]. C.E. Ellis, Wet air oxidation of refinery spent caustic, Environmental Progress. 17(1) (1998) 28-30.

[18]. N. Keramati, A. Moheb, M.R. Ehsani, NaOH Recovery from MEROX Tower Waste Stream Using the Electrodialysis Process, Separation Science and Technology. 46(1) (2010) 27-32.

[19]. J. Levec, A. Pintar, Catalytic wet-air oxidation processes: a review, Catalysis Today. 124(3) (2007) 172-184.

[20]. L. Zhang et al., Chemical and biological technologies for hydrogen sulfide emission control in sewer systems: a review, Water research. 42(1) (2008) 1-12.

[21]. A. Gonzalez-Sanchez, S. Revah, Biological sulfide removal under alkaline and aerobic conditions in a packed recycling reactor, Water Science and Technology. 59(7) (2009) 1415.

[22]. A. Kolhatkar, K.L. Sublette, Biotreatment of refinery spent sulfidic caustic by specialized cultures and acclimated activated sludge, Applied biochemistry and biotechnology. 57(1) (1996) 945-957.

[23]. J.J. Park et al., Application of spent sulfidic caustics for autotrophic denitrification in a MLE process and their microbial characteristics by fluorescence in situ hybridization, Korean Journal of Chemical Engineering. 25(3) (2008) 542-547. 
[24]. B. Rajganesh et al., Biotreatment of refinery spent sulfidic caustics, Biotechnology progress. 11(2) (1995) 228-230.

[25]. E. Smet, H. Van Langenhove, Abatement of volatile organic sulfur compounds in odorous emissions from the bio-industry, Biodegradation. 9(3-4) (1998) 273-284.

[26]. D.H. Zitomer, D. Owens, R.E. Speece, Methanethiol production as an indicator of toxicity in anaerobic treatment, Water science and technology. 42(5-6) (2000) 231-235.

[27]. D.Y. Sorokin et al., Thioalkalimicrobium aerophilum gen. nov., sp. nov. and Thioalkalimicrobium sibericum sp. nov., and Thioalkalivibrio versutus gen. nov., sp. nov., Thioalkalivibrio nitratis sp. nov., novel and Thioalkalivibrio denitrificancs sp. nov., novel obligately alkaliphilic and obligately chemolithoautotrophic sulfur-oxidizing bacteria from soda lakes, International Journal of Systematic and Evolutionary Microbiology. 51(2) (2001) 565-580.

[28]. D.Y. Sorokin et al., Thioalkalispira microaerophila gen. nov., sp. nov., a novel lithoautotrophic, sulfur-oxidizing bacterium from a soda lake, International Journal of Systematic and Evolutionary Microbiology. 52(6) (2002) 2175-2182.

[29]. K.Y. Chen, J.C. Morris, Kinetics of oxidation of aqueous sulfide by oxygen, Environmental Science \& Technology. 6(6) (1972) 529-537.

[30]. A. González-Sánchez, S. Revah, The effect of chemical oxidation on the biological sulfide oxidation by an alkaliphilic sulfoxidizing bacterial consortium, Enzyme and microbial technology. 40(2) (2007) 292-298.

[31]. F.J. Millero et al., Oxidation of $\mathrm{H} 2 \mathrm{~S}$ in seawater as a function of temperature, $\mathrm{pH}$, and ionic strength, Environmental science \& technology. 21(5) (1987) 439-443.

[32]. D. Sorokin et al., Isolation and properties of obligately chemolithoautotrophic and extremely alkali-tolerant ammonia-oxidizing bacteria from Mongolian soda lakes, Archives of microbiology. 176(3) (2001) 170-177.

[33]. D.A. Benson et al., GenBank, Nucleic acids research. 36(suppl 1) (2008) D25-D30.

[34]. S.B. Primrose, R. Twyman, Principles of gene manipulation and genomics. 2013: John Wiley \& Sons.

[35]. D.Y. Sorokin, J.G. Kuenen, Haloalkaliphilic sulfur-oxidizing bacteria in soda lakes, FEMS Microbiology Reviews. 29(4) (2005) 685-702.

[36]. S. Gadekar, M. Nemati, G.A. Hill, Batch and continuous biooxidation of sulphide by Thiomicrospira sp. CVO: reaction kinetics and stoichiometry, Water research. 40(12) (2006) 2436-2446.

[37]. H. Banciu et al., Fatty acid, compatible solute and pigment composition of obligately chemolithoautotrophic alkaliphilic sulfur-oxidizing bacteria from soda lakes, FEMS microbiology letters. 243(1) (2005) 181-187.

[38]. C.H. Lim et al., Optimization of growth medium for efficient cultivation of Lactobacillus salivarius i 24 using response surface method, Yeast. 1 (2007) 1-5.

[39]. H.L. Banciu et al., Influence of salts and $\mathrm{pH}$ on growth and activity of a novel facultatively alkaliphilic, extremely salt-tolerant, obligately chemolithoautotrophic sufur-oxidizing Gammaproteobacterium Thioalkalibacter halophilus gen. nov., sp. nov. from South-Western Siberian soda lakes, Extremophiles. 12(3) (2008) 391-404.

[40]. D.P. Kelly, L.A. Chambers, P.A. Trudinger, Cyanolysis and spectrophotometric estimation of trithionate in mixture with thiosulfate and tetrathionate, Analytical Chemistry. 41(7) (1969) 898-901.

[41]. J.M. Cha, W.S. Cha, J.h. Lee, Removal of organo-sulphur odour compounds by Thiobacillusnovellus SRM, sulphur-oxidizing microorganisms, Process Biochemistry. 34(6) (1999) 659-665. 